\title{
Impact of implementing an Internal Bed Regulation Committee on administrative and care indicators at a teaching hospital
}

\author{
Resultado da implantação de um Núcleo Interno de Regulação de Leitos nos \\ indicadores administrativo-assistenciais em um hospital de ensino
}

Luciane Cristine Ribeiro Rodrigues ${ }^{1}$, Carmen Maria Casquel Monti Juliani²

\begin{abstract}
Objective: To compare hospital indicators before and after implementing an Internal Bed Regulation Committee at a reference hospital. Methods: It is an quantitative, evaluation, exploratory, descriptive and cross-sectional research. The data was gathered from the hospital administrative reports for the period 2008-2013, provided by the Information Technology Center of the Complexo FAMEMA. Results: The indicators improved after implementation of the Internal Bed Regulation Committee. Conclusion: The individuals involved in the process acknowledged the improvement. It is necessary to carry on the regulatory actions, especially in a comprehensive and complex healthcare system, such as the brazilian Sistema Único de Saúde.
\end{abstract}

Keywords: Hospital administration; Bed occupancy; Health services accessibility; Health care regulation and supervision; Health status indicators

\section{RESUMO}

Objetivo: Comparar indicadores hospitalares antes e após a implantação de um Núcleo Interno de Regulação de Leitos em um hospital de referência. Métodos: Pesquisa avaliativa, exploratória, descritiva e transversal, de natureza quantitativa. Os dados apresentados foram extraídos de relatórios administrativos do hospital, fornecidos pelo Núcleo Técnico de Informática do Complexo Famema, abrangendo o período de 2008 a 2013. Resultados: Os indicadores apresentaramse melhores após a implantação do Núcleo Interno de Regulação. Conclusão: As melhorias foram sentidas pelos sujeitos envolvidos no processo. Há necessidade de continuidade das ações regulatórias, em especial em um sistema de saúde abrangente e complexo, como é 0 Sistema Único de Saúde na realidade brasileira.
Descritores: Administração hospitalar; Ocupação de leitos; Acesso aos serviços de saúde; Regulação e fiscalização em saúde; Indicadores básicos de saúde

\section{INTRODUCTION}

Throughout the years, the Ministry of Health has launched some strategies to meet the health demands of the population. These have been published in ordinances, which recommend norms and strategies aiming at access to actions and services necessary to optimize beds and reorganize care. Among these proposals, we find the decentralization of accomplishment, control, assessment, and regulation of the health system, which implies in structural and managerial changes, as well as preparing and developing new methods and instruments. ${ }^{(1)}$

One strategy used by the Sistema Único de Saúde (SUS) [national healthcare system in Brazil] to guarantee such directives and to provide quality health care is the organization of central stations to regulate care provision, aiming to adjust the flow of health actions according to supply and demand of health services.

Regulation may be understood as the ordering and orienting regulatory action of care flow, also responsible for the mechanism of interface between management and the many health services, in addition to delivering

\footnotetext{
Faculdade de Medicina de Marília, Marília, SP, Brasil.

2 Universidade Estadual Paulista "Júlio de Mesquita Filho", Botucatu, SP, Brasil.

Corresponding author: Luciane Cristine Ribeiro Rodrigues - Avenida Monte Carmelo, 795 - Bairro Fragata C - Zip code: 17519-030 - Marilia, SP, Brasil - Phone: (14) 3402-1719 - E-mail: lucianer@famema.br Receveid on: July 31, 2014 - Accepted on: Jan 10, 2015

Conflict of interest: none.
}

DOI: 10.1590/\$1679-45082015GS3235 
alternative care that is more appropriate to the citizens' needs, in an equanimous, ordered, timely and rational fashion. ${ }^{(1-4)}$

The benefits for the population may be seen in the reduced repressed demand number of repressed cases, as a consequence of timely and ordered access to healthcare services, as well as directly by users, making schedule of appointments easier. ${ }^{(5)}$

In management, the regulatory process favors case resolution in an efficient way, providing a deeper and more dynamic understanding of the health network, and favoring the identification of critical areas and of the health needs in a more comprehensive way. This type of process generates even better control over health expenditures, better use of resources, and quality in health services provision. ${ }^{(5)}$ Therefore, in management, it can generate, calculate, and monitor hospital efficiency indicators, in order to make managerial decisions.

The regulation may be characterized from the user's daily access standpoint (microregulation), as well as by the definition of policies in the organizations (macroregulation). ${ }^{(4,6)}$ This need for services regulation was reinforced in Decree no. 7,508 that regulates the Lei Orgânica da Saúde Organic Health Law. ${ }^{(6)}$

Considering the demand determined by the high volume of services and the organization's commitment to improving internal management of beds, the Internal Regulation Committee (NIR, acronym in Portuguese) was implemented in the Complexo Assistencial da Faculdade de Medicina de Marília (FAMEMA), wich was the topics of his study from 2010 to 2013. The NIR comprises complementary resources, such as advisory board, NIR team, statistics and information system, with well-defined competences. Their missions include to be the observatory of the admission system for the Complexo Assistencial da FAMEMA, to input data in the Hospital Information System, and to provide quantitative and qualitative reports of hospital indicators. The team is composed of a regulating physician, two nurses, and one secretary.

Considering the statement that care and management are truly inseparable, it should be emphasized the need for "indicators that represent of what happens in the working process", which can point to possible changes in the services and in development of individuals. ${ }^{(7)}$

An indicator is defined as a measurement unit of an activity, which is correlated to a quantitative measurement that, in turn, is a guide to monitor and assess care quality and the activities of a service. ${ }^{(8)}$

Therefore, the guiding question of the research was: Were there changes in the indicators after implementing the regulatory process done by the NIR?
Within this context, this study is justified since it evaluates the implementation of this process related to management in the context of the hospital. By analyses of these results, it is possible to identify positive data or not, and keep improving continuously.

\section{OBJECTIVE}

To compare hospital indicators before and after the implementation of the Internal Bed Regulation Committee in a reference hospital.

\section{METHODS}

It is an evaluation, exploratory, descriptive and longitudinal study, conducted in hospital inpatients units of the Complexo Assistencial da FAMEMA, in the city of Marília (SP), which has approximately 216 thousand inhabitants. It is a teaching hospital, and a reference hospital for one region of the state, which implemented bed regulation in the second semester of 2010.

The data presented were extracted from administrative reports of the hospital, and provided by the Information Technology Center of the Complexo FAMEMA, from 2008 to 2013.

The following indicators were gathered and analyzed: percentage of surgeries cancelled from 2008 to 2013 (due to bed shortage and as compared to scheduled surgeries); ratio of scheduled and not scheduled surgeries from 2010 to 2013 (since there were no data available before 2010); number of patients who were admitted directly to the operating room, staying there during the postoperative period (2008 to 2013); number of patients who were admitted directly to the operating room and sent to the emergency department in postoperatively (2008 to 2013); and number of patients who came back to the emergency department in the postoperative period (2008 to 2013).

The indicators were evaluated considering their decrease in absolute numbers or percentages, considering that a drop in inappropriate situations related to the abovementioned indicators was expected after implementing the committee.

In regard to ethical aspects, there was no need to ask for Informed Consent since these are administrative data that do not concern patients directly, nor the employees of the organization. The study was submitted and approved by FAMEMA's Research Ethics Committee (number 563/11).

\section{RESULTS}

According to some initial results presented, three years after implementing the internal bed regulation in the 
Complexo FAMEMA, some hospital indicators changed, pointing to a likely correlation with bed regulation. Some of those indicators were most closely related to sectors more directly connected to the regulatory action, such as the operating room and the emergency department.

The operating room, integrated to the many surgical specialties that use it, represented one of the units with the highest percentage of use of the bed regulation service, for both elective demands and emergencies.

Another situation observed was surgery cancellation, which should not happen. This is due to many factors, such as bed shortage in the postoperative period. During the period studied, the regulation action led to a decrease in cancelled surgical procedures in relation to scheduled surgeries, and there were less cancellations due to shortage of hospital beds, as depicted in table 1 .

Table 1. Percentage of surgical procedures cancelled in relation to the total scheduled surgeries and due to shortage of bed in the unit and/or intensive care unit. Marília, 2008 to 2013

\begin{tabular}{|c|c|c|c|c|c|c|}
\hline Reason & $\begin{array}{c}2008 \\
(\%)\end{array}$ & $\begin{array}{c}2009 \\
(\%)\end{array}$ & $\begin{array}{c}2010 \\
(\%)\end{array}$ & $\begin{array}{c}2011 \\
(\%)\end{array}$ & $\begin{array}{c}2012 \\
(\%)\end{array}$ & $\begin{array}{c}2013 \\
(\%)\end{array}$ \\
\hline $\begin{array}{l}\text { Surgeries cancelled as compared to } \\
\text { total scheduled surgeries }\end{array}$ & 22.53 & 23.78 & 23.87 & 25.26 & 16.01 & 19.75 \\
\hline $\begin{array}{l}\text { Surgeries cancelled due to bed shortage } \\
\text { in the units }\end{array}$ & 8.2 & 4.8 & 6.6 & 0.4 & 2.0 & 6.7 \\
\hline $\begin{array}{l}\text { Surgeries cancelled due to bed shortage } \\
\text { at the intensive care unit }\end{array}$ & 1.0 & 1.9 & 2.2 & 1.9 & 2.4 & 4.4 \\
\hline
\end{tabular}

It is important to emphasize that some indicators increased in some of the periods analyzed due to strikes in the organization. From December 2011 to January 2012, and August to October 2013, there were a few strikes in the organization, what reflected directly in the hospital indicators, mainly those related to the operating room. These periods of strike, when there was reduced manpower, implied in less workers and beds available, resulting in cancellation of some surgeries. Regardless of this fact, the indicator worsened in relation to the previous year (2012), but not in relation to the years prior to the implementation of NIR.

Another important factor was that some medical specialties began to use the service of bed regulation only as from 2012, what explains the rise in surgeries cancellation due to a shortage in beds between 2011 and 2012, and even in 2013, in spite of the strike. With the increased demand of beds to the NIR, there was greater imbalance in demand in relation to supply of bed. Nevertheless, in this context, NIR and the operating room could work more closely, in a homogeneous movement with continuous dialogue, identifying possible elective surgeries that would take place with no guarantee of beds in the postoperative period, thanks to the work with the medical specialties, in order to guarantee previous scheduling and organization of surgical demands. Aware of the admission demands, the NIR was able to establish priorities, as well as look for alternatives for admissions, according to the degree of complexity of the cases and the approval from the medical specialties, therefore reducing the number of surgeries cancelled.

Considering it was a new proposal at the organization, the physicians progressively complied with the regulations since their implementation, but, in some cases, they resist to the innovation. To this day some specialties are still in the process of complying to the regulation.

In relation to surgeries flow, another change in the indicators was the reduction of the number of surgeries "fit in between", surgeries not scheduled in relation to the surgeries scheduled in the specialties that used the bed regulation, as depicted in table 2 .

Table 2. Percentage of scheduled and not scheduled surgeries, according to the medical specialties

\begin{tabular}{|c|c|c|c|c|c|c|c|c|}
\hline \multirow{2}{*}{$\begin{array}{l}\text { Medical } \\
\text { specialties }\end{array}$} & \multicolumn{2}{|c|}{2010} & \multicolumn{2}{|c|}{2011} & \multicolumn{2}{|c|}{2012} & \multicolumn{2}{|c|}{2013} \\
\hline & $\mathbf{S}$ & NS & $\mathbf{S}$ & NS & $\mathbf{S}$ & NS & $\mathbf{S}$ & NS \\
\hline Specialty 1 & 35.7 & 64.3 & 68.6 & 31.4 & 68.7 & 31.3 & 60.5 & 39.5 \\
\hline Specialty 2 & 35.0 & 65.0 & 73.2 & 26.8 & 68.8 & 31.2 & 65.6 & 34.4 \\
\hline Specialty 3 & 22.2 & 77.8 & 37.3 & 62.7 & 42.4 & 57.6 & 62.1 & 37.9 \\
\hline Specialty 4 & 43.2 & 56.8 & 68.7 & 31.3 & 63.2 & 36.8 & 41.9 & 58.1 \\
\hline Specialty 5 & 23.3 & 76.7 & 43.0 & 57.0 & 52.9 & 47.1 & 36.0 & 64.0 \\
\hline Specialty 6 & 30.4 & 69.6 & 85.2 & 14.8 & 79.2 & 20.8 & 69.5 & 30.5 \\
\hline Specialty 7 & 26.3 & 73.7 & 61.1 & 39.9 & 60.9 & 39.1 & 62.6 & 37.4 \\
\hline Specialty 8 & 49.5 & 50.5 & 87.4 & 12.6 & 80.7 & 19.3 & 78.8 & 21.2 \\
\hline Specialty $9^{*}$ & 18.5 & 81.5 & 40.5 & 59.5 & 35.4 & 64.6 & 27.2 & 72.8 \\
\hline Specialty $10^{*}$ & 14.0 & 86.0 & 37.2 & 62.8 & 33.1 & 66.9 & 38.0 & 62.0 \\
\hline
\end{tabular}

*Medical specialties that were not complying with the internal bed regulation when data was collected $\mathrm{S}=$ scheduled; NS = non-scheduled

An inversion in the ratio of scheduled and not scheduled surgeries was observed. This was a trend in most specialties analyzed that used the service of bed regulation, since they started to make anticipated, programed orders for beds for surgical demands. As a consequence, this changed the profile of scheduled surgeries and led to less non-scheduled surgeries. It is possible to observe different profiles among the specialties that used bed regulation as compared to those that did not use it. It became evident that the 
specialties that ordered beds before surgeries had an increased number of scheduled surgeries.

The operating theater is one of the priority sectors of NIR and, from this stance, some changes in the dynamics of data of that sector were observed. First, there were cases admitted directly to the operating room due to diverse factors, such as urgencies, bed shortage upon admission, no scheduling and no previous bed ordering, difficulty in the communication process between different departments, etc. Therefore, the patients remained in that department after surgery. These facts led to a differentiation in indicators after bed regulation, as depicted in table 3 .

The data also demonstrated the reduction in the number of patients who remained in the operating room after the surgery. This trend towards profile change could be more intensely observed in the specialties that used the NIR service up to the moment of data collection.

Another piece of data with positive alteration was the number of patients referred to the emergency department after surgery. This had always been common practice in the organization but it decreased significantly when giving priority to bed regulation at the operating room in, as shown in table 4.

This situation also decreased, that is, there was a significant drop in the number of patients who were admitted directly to the operating room and who were referred to the emergency department after the surgery. Furthermore, there was a reduction in patients returning to the emergency department after surgery. Therefore, we noted that the regulatory action led to decreased postoperative referral to an inappropriate department.

Table 3. Number of patients who were admitted directly the operating room and who remained there after the surgery

\begin{tabular}{|c|c|c|c|c|c|c|c|c|}
\hline Admission sector & Second or single move & Surgical team map & 2008 & 2009 & 2010 & 2011 & 2012 & 2013 \\
\hline \multirow[t]{10}{*}{ Operating room } & Operating room & Specialty 1 & 204 & 199 & 24 & 16 & 9 & 15 \\
\hline & & Specialty 2 & 71 & 169 & 128 & 119 & 35 & 21 \\
\hline & & Specialty 3 & 21 & 64 & 29 & 16 & 14 & 16 \\
\hline & & Specialty 4 & 2 & 8 & 33 & 56 & 20 & 14 \\
\hline & & Specialty 5 & 1 & 3 & 3 & 1 & - & - \\
\hline & & Specialty 6 & 276 & 253 & 191 & 155 & 65 & 40 \\
\hline & & Specialty 7 & 6 & 37 & 24 & 11 & 10 & 13 \\
\hline & & Specialty 8 & 4 & 32 & 65 & 114 & 58 & 32 \\
\hline & & Specialty $9^{*}$ & 3 & 12 & 4 & 6 & 7 & 7 \\
\hline & & Specialty $10^{*}$ & 19 & 10 & 11 & 15 & 13 & 8 \\
\hline Total & & & 607 & 787 & 512 & 509 & 231 & 166 \\
\hline
\end{tabular}

${ }^{*}$ Medical specialties that, up to the moment of data collection did not comply with the internal bed regulation.

Table 4. Number of patients directly admitted to the operating room or to the emergency department and who were referred to the emergency department after surgery

\begin{tabular}{|c|c|c|c|c|c|c|c|c|}
\hline Entry department & Second or single move & Surgical team map & 2008 & 2009 & 2010 & 2011 & 2012 & 2013 \\
\hline \multirow[t]{10}{*}{ Operating room/ emergency department } & Emergency department & Specialty 1 & 544 & 499 & 119 & 93 & 25 & 14 \\
\hline & & Specialty 2 & 13 & 16 & 11 & 4 & 4 & 4 \\
\hline & & Specialty 3 & 205 & 318 & 107 & 114 & 23 & 13 \\
\hline & & Specialty $4^{*}$ & - & - & - & - & - & - \\
\hline & & Specialty 5 & 6 & 3 & 10 & 20 & 2 & - \\
\hline & & Specialty 6 & 123 & 76 & 15 & 12 & 6 & 3 \\
\hline & & Specialty 7 & 12 & 36 & 28 & 8 & 3 & 6 \\
\hline & & Specialty 8 & - & 1 & 2 & 1 & 2 & 1 \\
\hline & & Specialty $9^{* *}$ & 15 & 9 & 15 & 10 & 2 & 6 \\
\hline & & Specialty $10^{* *}$ & 71 & 64 & 97 & 104 & 84 & 32 \\
\hline Total & & & 989 & 1.022 & 404 & 366 & 151 & 79 \\
\hline
\end{tabular}

*Specialty 4: no information; ** medical specialties that did not comply with the internal bed regulation up to data collection.

\section{DISCUSSION}

Considering the working process of the NIR, the operating room, the intensive care units and the emergency room are priority areas in bed regulation, since these sectors are responsible for the large turnover of patients at the hospital. 
The operating room is considered a priority unit at hospitals due to flow of most surgical cases, and it can be more dynamic, expediting or not the turnover of new cases, or hindering the organizational flow. ${ }^{(9)}$

Taking into account that the NIR deems the operating room as priority area in bed regulation, a close relation between the drop in cancelled surgeries due to bed shortage and bed regulation can be observed.

Nevertheless, as we may observe especially in 2013, this trend toward reduction intensified, what may be associated to the direct influence that the strike had over the results analyzed.

Another important factor is that some medical specialties began to use the bed regulation service from 2012 on, what explains the increase in surgery cancellation due to bed shortage, between 2011 and 2012, and even in 2013, in spite of the strike. The increasing demands for bed at the NIR led to a larger imbalance of demand in relation to bed supply. However, in such context, it was possible to establish a closer relation between the NIR and the operating room, in a homogeneous movement with continuous dialogue, identifying elective surgeries that would occur with no guarantee of a postoperative bed, working together with the surgical specialties to schedule previously and organize the surgical demands. The NIR, aware of the admission demands, could establish priorities, according to surgical criteria, in addition to looking for possible alternatives for admissions, according to degree of complexity of the cases and in agreement with the surgical specialties, thus reducing the number of surgeries cancelled.

This profile still goes through fluctuations, especially due to the residents' turnover in the medical specialties, generating a movement of continuous construction in the working process.

In this context of surgery cancellation, we can verify the repercussions in the organization and also consider what directly affects patients and families, who prepare themselves psychologically, physically, and financially to face the stressful situation generated by the fear of an unknown event to handle. For the organization, cancelling surgeries interferes in the working processes of the teams, as well as in unnecessary use of material and waste of time. ${ }^{(10,11)}$

Another important aspect was that surgery cancellations impacted directly on the assessment of hospital efficiency, since it is considered that an efficient surgical department should have a low rate of surgeries cancellation, otherwise it might become an underused sector, with the consequent increases in surgical demand and costs. ${ }^{(12)}$
Studies related to this same topic pointed to varied surgical cancellation rates: Perroca et al. ${ }^{(13)}$ found a total of $5.1 \%$ cancelled surgeries, $29.1 \%$ of those due to bed shortage; Zafar et al. ${ }^{(14)}$ registered $25 \%$ cancellation, $16.2 \%$ due to bed shortage.

Another study presented surgery cancellation rates of $11.4 \%$ where $6.0 \%$ were due to bed shortage in the intensive care unit ${ }^{(11)}$ Pittelkow and Carvalho ${ }^{(15)}$ found $19.9 \%$ cancellations, $2.1 \%$ due to lack of beds in beds in the intensive care unit.

As pointed by the data analyzed, it was possible to observe an inversion in the number of surgeries scheduled in relation to those not scheduled, this trend being observed in most specialties analyzed and that used the bed regulation service, since they started to order the beds for surgical demand in advance, in a programed way. The result changed the profile of surgeries scheduled in detriment of those not scheduled.

Therefore, it is possible to observe the different profile among the specialties that complied with bed regulation as compared to those who were non compliant, at the time of this study. It became evident that for the specialties that ordered beds before surgeries, there was an increase in the number of scheduled surgeries. This may be an indicative that regulation favors surgery planning and programing, avoiding improvisation that has negative repercussion on the working process and, inevitably, on users. It is important to emphasize that these data were initially observed after the implementation of the NIR hence, the years previous to the regulation were not addressed.

One caveat was that two medical specialties presented a significant increase in the number of surgeries not scheduled in 2013 due to an increase in urgency and emergency cases. This resulted in increased number of not scheduled surgeries when compared to scheduled surgeries that year.

Another change observed was related to the significant drop in the number of patients who entered directly to the operating theater and were referred to the emergency department after the surgery. Moreover, there was a reduction in the number of patients who came back to the emergency department postoperatively.

In some hospitals, as is the case of the Hospital de Urgências de Sergipe and the Hospital Regional do Mato Grosso do Sul, ${ }^{(9)}$ the historical situation is very similar to the Complexo FAMEMA, with stretchers in the corridor of the emergency department, patients staying in the recovery room of the operating room longer than expected, and patients coming back to the emergency 
department after surgery. Such realities improved after the implementation of bed regulation, despite the fact that this is still a partial experience.

We found other realities that support the perception of the workers at Complexo FAMEMA in relation to the NIR regarding the strategies to solve the problem of emergency department overcrowding, since it is a core device to expedite patients' discharge from some units, such as the operating room. ${ }^{(9,16,17)}$

Regulation also expressed the managers intention to establish a communication and conciliation channel between the care units, in order to promote access to health services. ${ }^{(18)}$

The profile changes observed after the installment of the Internal Bed Regulation Committee altered the historic organization context, and indicated the need for further follow-up studies. The aim is to continue and better clarify data analysis in regard to the possible contributions of bed regulation to the organization, with statistical refinement that express significance.

As limitation of the study, we can mention the fact that, concurrent to the proposal of implementing bed regulation, 40 new beds were made available at a new unit of the hospital complex and, later, 12 more beds were transferred from the Hospital de Clínicas to this intermediate-complexity unit. This fact may have been one of the indications of change in the high-complexityunit indicators, once the intermediate- and lowcomplexity cases that would necessarily be allocated to that unit, be them surgical or clinical, and were gradually transferred to the new unit.

In spite of this limitation, the improvement in the indicators was undeniable, and this fact, in honor of zeal and strictness in the analysis, does not alter the value of the proposal implemented, which points to palpable results demonstrated by means of some indicators. Moreover they were perceived and reported by the workers in the daily hospital activities.

\section{CONCLUSION}

The indicators presented positive changes with the implementation of the Internal Regulation Committee. These data are in consonance to the improvement observed by the subjects involved in the process.

The results indicate the need of continuity of the regulatory actions, especially in a comprehensive and complex healthcare system such as the Sistema Único de Saúde (SUS) [Unified Health System], in the Brazilian reality.

\section{REFERENCES}

1. Brasil. Ministério da Saúde. Secretaria de Assistência à Saúde. Departamento de Descentralização da Gestão da Assistência. Regionalização da assistência à saúde: aprofundando a descentralização com equidade no acesso: Norma Operacional da Assistência à Saúde. Noas - SUS 01/02. Portaria n. 373 de 27 de Fevereiro de 2002 e regulamentação complementar. [Internet] 2.ed. Brasília, DF: Ministério da Saúde, 2002. [citado 2014 Ago 14]. Disponível em: http://dtr2001.saude.gov.br/sas/caderno\%20NOAS\%2002.pdf

2. Brasil. Ministério da Saúde. A política de regulação do Brasil. Brasília (DF): Organização Pan-Americana da Saúde. Brasília; 2006. [Série Técnica Desenvolvimento de Sistemas e Serviços de Saúde, 12].

3. Brasil. Ministério da Saúde. Secretaria de Atenção à Saúde. Departamento de Regulação, Avaliação e Controle de Sistemas. Diretrizes para a implantação de complexos reguladores. Brasília, DF: Ministério da Saúde, 2006.

4. Santos FP, Merhy EE. A regulação pública da saúde no Estado brasileiro - uma revisão. Interface (Botucatu). 2006;10(19):25-41.

5. Oliveira RR. Os conceitos de regulação em saúde no Brasil [dissertação]. São Paulo: Faculdade de Medicina, Universidade de São Paulo; 2002.

6. Brasil. Ministério da Saúde. Secretaria de Atenção à Saúde. Departamento de Regulação, Avaliação e Controle de Sistemas. Curso básico de regulação, controle, avaliação e auditoria no SUS. 2.ed. Brasília, DF: Ministério da Saúde, 2011. [Série F. Comunicação e Educação em Saúde].

7. Brasil. Ministério da Saúde. Secretaria de Atenção à Saúde. Núcleo Técnico da Política Nacional de Humanização. Monitoramento e avaliação na política nacional de humanização na rede de atenção e gestão do SUS: manual com eixos avaliativos e indicadores de referência. Brasília, DF: Ministério da Saúde, 2009. [Série B.Textos Básicos de Saúde].

8. Kurcgant $\mathrm{P}$, Tronchin DM, Melleiro MM. A construção de indicadores de qualidade para a avaliação de recursos humanos nos serviços de enfermagem: pressupostos teóricos. Acta Paul Enferm. 2006;19(1 Supl 1):88-91.

9. Bitencourt RJ, Prudente L, Scarazatti GL, Amaral MA. Gestão de leitos e vagas hospitalares: relato de experiências do Hospital de Urgência de Sergipe [Internet]. In: QualiHOSP 2009 - Congresso Internacional de Qualidade em Serviços e Sistemas de Saúde; 2009; 6-8; São Paulo. Anais. São Paulo; 2009 [citado 2014 Ago 14]. Disponível em: http://www.logisticareversa.net.br/ uploads/1/6/3/0/1630201/anais_qualihosp_2009.pdf

10. Koppada B, Pena M, Joshi A. Cancellation in elective orthopaedic surgery. Health Trends. 1991;23(3):114-5.

11. Paschoal ML, Gatto MA. Taxa de suspensão de cirurgia em um hospital universitário e os motivos de absenteísmo do paciente à cirurgia programada. Rev Lat Am Enfermagem. 2006;14(1):48-53.

12. Mangan JL, Walsh C, Kernohan WG, Murphy JS, Mollan RA, McMillen R, et al. Total joint replacement: implication of cancelled operations for hospitalcosts and waiting list management. Qual Health Care. 1992;1(1):34-7.

13. Perroca MG, Jericó Mde C, Facundin SD. Monitorando o cancelamento de procedimentos cirúrgicos: indicador de desempenho organizacional. Rev Esc Enferm USP. 2007;41(1):113-9.

14. Zafar A, Mufti TS, Griffin S, Ahmed S, Ansari JA. Cancelled elective general surgical operations in Ayub Teaching Hospital. J Ayub Med Coll Abbottabad. 2007;19(3):64-6.

15. Pittelkow E, Carvalho R. Cancelamento de cirurgias em um hospital da rede pública. Einstein (São Paulo). 2008:6(4):416-21.

16. Bitencourt RJ. A superlotação dos serviços de emergência hospitalar como evidência de baixo desempenho organizacional [tese]. Rio de Janeiro: Escola Nacional de Saúde Pública Sergio Arouca, Fundação Oswaldo Cruz; 2010. 
17. Bitencourt RJ, Hortale VA. [Interventions to solve overcrowding in hospital emergency services: a systematic review]. Cad Saude Publica. 2009;25(7): 1439-54. Review. Portuguese.
18. Albuquerque MS, Lima LP (in memorian), Costa AM, Filho DA. Regulação assistencial no Recife: possibilidades e limites na promoção do acesso. Saúde Soc. 2013;22(1):223-36. 